\title{
Metode Permainan Dalam Meningkatkan Pemahaman Firman Tuhan Pada Remaja GKII Okahapi Sumba Timur
}

\section{Game Methods in Improving Understanding of God's Word in GKII Youth in Okahapi, East Sumba}

\author{
Serli ${ }^{1)}$ \\ Hengki Wijaya ${ }^{2)^{*}}$ \\ 1) Sekolah Tinggi Filsafat Theologia Jaffray Makassar \\ 2) Sekolah Tinggi Filsafat Theologia Jaffray Makassar \\ *Penulis Korespondensi: hengkilily1988@gmail.com
}

Received: 2403 2020/Revised: 2005 2020/ Accepted: 11062020

\begin{abstract}
Abstrak
Tujuan penulisan artikel ini adalah untuk mengetahui bagaimana pengaruh metode permainan dalam meningkatkan pemahanan firman Tuhan pada remaja GKII Okahapi Sumba Timur. Metode penelitian yang digunakan dalam penulisan artikel ini adalah dengan menggunakan metode kuantitatif. Metode penelitian kuantitatif yaitu kajian perpustakaan, observasi langsung di lapangan, metode wawancara, peneliti mengadakan wawancara pada objek langsung dalam hal ini adalah remaja GKII Okahapi Sumba Timur untuk memperoleh jawaban yang diperlukan, angket atau kuesioner, dengan cara membagikan angket atau kuesioner. Dari pembahasan yang ada, maka penulis menarik kesimpulan bahwa hasil analisis menunjukkan bahwa $\mathrm{X}_{2}$ memengaruhi indikator $Y_{2}$ yang paling besar di antara indikator yang lain, yaitu sebesar $95 \%$. Hal ini menunjukkan bahwa metode bermain peran memiliki pengaruh yang besar dalam meningkatkan pemahaman firman Tuhan dalam membangun persekutuan yang benar di dalam Tuhan. Penerapan bermain peran membantu anak remaja untuk dapat mengerti cara untuk membangun persekutuan yang benar di dalam Tuhan. Anak remaja dengan pemahaman yang dimiliki dapat merangkumkan makna yang diperoleh dari bermain peran.
\end{abstract}

Kata-kata Kunci: Metode, Permainan, Ibadah, Pemahaman, Firman Tuhan.

\begin{abstract}
The purpose of writing this article is to find out how the influence of the game method in increasing the comprehension of God's word on GKII East Okaapi Sumba youth. The research method used in writing this article is to use quantitative methods. Quantitative research methods, namely library studies, direct observation in the field, interview methods, researchers conducted interviews on direct objects, in this case, the teenager GKII Okahapi East Sumba to obtain the required answers, questionnaire, or
\end{abstract}


questionnaire, by distributing surveys or questionnaires. From the discussion, the authors conclude that the analysis shows that $\mathrm{X} 2$ influences the most significant $\mathrm{Y} 2$ indicator among the other, which is $95 \%$. It shows that the role-playing method has a significant influence on increasing the understanding of God's word in establishing a true fellowship in God. The application of role-playing helps teenagers to understand ways to build true friendship in God. Teenagers with understanding can summarize the meaning obtained from role-playing.

Keywords: Method, Games, Fellowship, Understanding, The Word of God.

\section{PENDAHULUAN}

Berdasarkan pengamatan penulis, GKII Okahapi Sumba Timur menghadapi permasalahan dalam ibadah remaja. Dalam persekutuan, remaja yang mengikuti ibadah bisa dihitung jari. Terdapat hambatan bagi anak-anak remaja maupun pemuda dalam mengikuti ibadah di GKII Okahapi Sumba Timur. Penulis menemukan beberapa masalah berkaitan dengan situasi ini.

Usia remaja-pemuda, mereka sedang berada dalam masa peralihan. Peralihan dari masa kanak-kanak ke usia remaja, dan dari usia remaja ke usia dewasa, yakni antara 12 sampai 21 tahun (Singgih D. Gunarsa \& Yulia Singgih D. Gunarsa, 2011, p. 203). Dalam masa tersebut, hal mendominasi perasaan yang dirasakan oleh remaja adalah rasa bosan dan tingkat kejenuhan tinggi. Apalagi jika kegiatan ibadah yang dilakukan tidak menarik menurut remaja, tidak ada hal yang mereka dapatkan dari ibadah tersebut, mereka akan lebih tertarik untuk tidak mengikuti kegiatan ibadah.

Faktor lain yang dapat diketahui berkaitan dengan hasil wawancara kegiatan ibadah yang monoton, kaku, terlalu lama, tidak ada interaksi yang terjadi antar pemimpin ibadah dan remaja lain, dan kurangnya pemahaman tujuan dari ibadah yang dilakukan. Dengan demikian, hal tersebut menyebabkan sebagian besar dari mereka lebih memilih untuk melakukan kegiatan lain yang dapat membuat mereka senang, dibandingkan dengan mengikuti kegiatan ibadah. Ini menjadi tantangan tersendiri bagi gereja dan para pemimpin remaja dan pemuda.

Salah satu upaya yang dapat dilakukan oleh pihak gereja untuk menindaklanjuti hal tersebut adalah dengan membuat jenis kegiatan ibadah bervariasi. Ibadah bervariasi yang dimaksudkan adalah ibadah yang berbeda dari ibadah yang sebelumnya. Dengan tujuan untuk menarik minat mereka mengikuti kegiatan ibadah. Berminat berarti suatu keadaan di mana seseorang tertarik atau suka terhadap sesuatu. Baik itu pekerjaan, tugas, kegiatan, dan lainnya. 
Hal yang sama diungkapkan oleh Slameto bahwa minat adalah suatu rasa lebih suka, rasa ketertarikan (Nurhasanah \& Sobandi, 2016, p. 137). Perlu diketahui bahwa tidak semua anak memiliki minat yang sama. Ada anak yang memiliki minat tinggi, tetapi ada juga yang rendah (Supardi, et al., 2015, p. 73). Sehingga ketika ibadah yang berlangsung tidak sesuai dengan harapan remaja, banyak di antaranya justru memilih untuk tidak mengikuti kegiatan ibadah, dan pergi ke tempat lain yang dapat membuatnya senang.

Salah satu strategi yang perlu dilakukan agar kegiatan ibadah tidak monoton dan kaku adalah dengan menambah metode permainan atau games dalam ibadah. Thomas Edison mendefinisikan metode permainan sebagai suatu cara penyajian bahan pelajaran melalui bentuk permainan (Edison, 2017, p. 133). Permainan yang dimaksud dapat berupa tebak kata, memperagakan tokoh, mencari teman, menghafal ayat, sambung kata, dan masih banyak lainnya. Tujuan dari metode ini adalah untuk melibatkan remaja dalam kegiatan ibadah. Dengan harapan untuk menghindari suasana ibadah yang monoton dan kaku. Menurut pakar psikologi, permainan adalah suatu metode yang sesuai untuk belajar keterampilan sosial karena permainan dapat menciptakan suasana yang santai dan menyenangkan (Gibasa et al., 2010, p. 1). Hal tersebut menjadi kebutuhan bagi anak remaja saat ini. Anak remaja tidak hanya sekadar bermain, tetapi ada manfaat yang dapat diperoleh dalam permainan tersebut.

Manfaat yang dapat diperoleh dari sebuah permainan adalah sebuah kejujuran, menambah pengetahuan tentang sesuatu, bekerja sama, aktif, fokus, konsentrasi dan untuk memberikan pemahaman terhadap makna dari sebuah permainan. Dalam sebuah permainan, aktivitas fisik, kognitif, afeksi, dan emosinya berkembang secara terpadu (Tim Budi Pekerti, 2001, p. 22). Itu berarti bahwa, tidak hanya sekadar bermain. Tetapi memiliki manfaat yang dapat mengembangkan kemampuan remaja untuk mengetahui bahkan mampu memahami apa yang sedang mereka pelajari dalam permainan.

Mampu memahami sesuatu adalah hal yang sangat penting bagi remaja. Hal ini dikarenakan seorang remaja akan rajin mengikuti kegiatan ibadah, jika mereka sebenarnya memahami apa yang sedang mereka lakukan, dan pemahaman tersebut ditunjukan melalui pengambilan kesimpulan dengan tindakan yang nyata. Dengan demikian, hal tersebut juga dapat menambah pemahaman remaja sehubungan dengan firman Tuhan yang akan disampaikan oleh pengkhotbah dalam ibadah. Memahami tidak berarti hanya sekadar tahu atau mengetahui. Tetapi lebih kepada mengerti apa yang telah dilakukan atau dipelajari. Seseorang dikatakan mampu memahami jika orang tersebut dapat menarik makna dari pesan-pesan atau petunjuk-petunjuk soal yang dihadapinya (Baharsyah, 2017, p. 12). Itu berarti bahwa setelah mengetahui, anak remaja mengerti dan memamami apa yang sedang dilakukan dan memperoleh makna dari hal yang dilakukan.

Berangkat dari masalah dan tersedianya metode permainan, penulis ingin melihat pengaruh dari metode tersebut terhadap pemahaman anak-anak remaja 
terhadap firman Tuhan. Terdapat beberapa penelitian yang menunjukkan adanya pengaruh yang dapat dihasilkan melalui metode permainan terhadap tingkat pemahaman. Dalam penelitian yang dilakukan oleh Nikmah, metode permainan tidak hanya memberikan hasil yang positif terhadap aktivitas pembelajaran, namun juga pada hasil belajar secara khusus dalam kelas IPA (Nikmah et al., 2013). Hapsari dan Wicaksono juga menemukan adanya pengaruh dari metode permainan terhadap pemahaman secara khusus dalam kelas PPKN (Hapsari \& Wicaksono, 2012, p. 1). Berdasarkan artikel-artikel tersebut terlihat ada pengaruh antara metode permainan terhadap pemahaman anak didik. Melalui artikel ini, penulis ingin melihat apakah terdapat pengaruh dari metode permainan terhadap pemahaman firman Tuhan anakanak remaja di GKII Okahapi Sumba Timur.

\section{TEORI}

\section{Metode Permainan}

Anwar memberikan pengertian tentang metode pembelajaran sebagai cara mengajar atau cara menyampaikan materi pelajaran kepada siswa yang sedang belajar (Anwar, 2018, pp. 126). Strategi atau metode penyampaian materi pembelajaran diperlukan agar materi atau pokok bahasan yang disampaikan mudah dipahami oleh siswa (Pradani et al., 2015, pp. 163). Seogeng dan Dewi menuliskan bahwa bermain merupakan naluri alami yang telah melekat pada diri anak sejak bayi (2015, pp. 3). Pada setiap anak, bermain itu adalah belajar, di mana dengan bermain, anak akan belajar berbagai hal tentang kehidupan sehari-hari (Khobir, 2013, pp. 197; Bayoe et al., 2019). Dyan dan Saeful juga menuliskan, belajar akan lebih bermakna jika seorang anak mengalami sendiri apa yang dipelajarinya, bukan mengetahuinya (Rahayu, 2018, pp. 49; Agung \& Astika, 2011). Metode permainan merupakan salah satu metode pembelajaran yang baik, di mana materi yang disampaikan dilakukan melalui kegiatan belajar yang menyenangkan, agar tercipta pemahaman baru bagi siswa, dan ada ketertarikan dari siswa untuk pelajaran yang diajarkan.

\section{Jenis Metode Permainan}

Dalam kegiatan bermain, tidak semua permainan dilakukan untuk semua kalangan usia yang sama, menggunakan metode yang sama, menggunakan cara dan bahan yang diperlukan sama, dan dapat mendukung kegiatan yang dilakukan oleh seorang anak. Beberapa ahli psikologi anak, seperti Smilansky, Piaget, dan Hoorn, menyampaikan paling tidak ada tiga jenis kegiatan bermain yang dapat mendukung pembelajaran anak, yaitu: bermain fungsional atau sensorimotor, bermain peran, bermain konstruktif (Masnipal, 2013, pp. 63-64). 


\section{Bermain Fungsional/Sensorimotor}

"Bermain fungsional atau sensorimotor dimaksudkan bahwa anak belajar melalui panca inderanya dan melalui hubungan fisik dengan lingkungannya" (Darmadi, 2018, pp. 75-76). Artinya bahwa, dalam sebuah permainan, dibutuhkan pengenalan yang benar dengan adanya hubungan fisik dengan keadaan yang terjadi disekitar lingkungan permainan. Hal tersebut dapat dilakukan melalui penglihatan, pendengaran, penciuman aroma disekitar tempat bermain, dan perasaan.

Kebutuhan sensorimotor anak didukung ketika anak-anak disediakan kesempatan untuk bergerak secara bebas, berhubungan dengan bermacam-macam bahan dan alat permainan, baik dalam dan di luar ruangan (Syarbini, 2014, p. 66). Ketika seorang anak sedang bermain, kegiatan yang dilakukan tidak dibatasi hanya pada keadaan di dalam atau keadaan di luar. Tetapi, anak diberikan kebebasan yang dapat dipertanggungjawabkan oleh seorang anak itu sendiri.

\section{Bermain Peran}

Bermain peran disebut juga dengan main simbolis, pura-pura, fantasi, imajinasi, atau main drama (Mutiah, 2015, p. 115). Bermain peran memungkinkan anak memproyeksikan dirinya ke masa depan dan menciptakan kembali masa lalu. Kualitas pengalaman bermian peran, tergantung pada beberapa faktor, seperti cukup waktu untuk bermain, ruangan yang memadai, dan adanya peralatan-peralatan yang cukup mendukung permainan yang dilakukan (Syarbini, 2014, p. 66). Dengan beberapa hal tersebut, dapat menciptakan suasana yang baik untuk menunjang kegiatan bermain anak.

Menurut Erikson, terdapat dua jenis bermain peran yaitu bermain peran mikro dan makro (Darmadi, 2018, p. 77). Bermain peran mikro dimaksudkan bahwa anak memainkan peran dengan menggunakan alat bermain berukuran kecil, seperti orangorangan kecil yang sedang berjual beli. Saat anak bermain peran mikro, serti bermain orang-orangan kecil, anak akan belajar untuk menghubungkan dan mengambil sudut pandang dari orang lain sesuai dengan karakter yang diperankan. Sedangkan bermain peran makro, anak yang secara langsung bermain memainkan peran tokoh (Darmadi, 2018, p. 77). Peran yang dilakukan disesuaikan dengan tema, misalnya berperan sebagai dokter, perawat, ibu, ayah, anak, dan saudara dalam sebuah keluarga.

\section{Bermain Konstruktif}

Bermain konstruktif adalah permainan dengan menggunakan bahan-bahan (material) yang disusun atau dikonstruksi sesuai kreativitas anak, sehingga menjadi suatu karya (2013, p. 136). Bahan-bahan yang dimaksud dapat berupa bahan cair maupun terstruktur. Seperti cat air, krayon, batu-batu, pasir, puzzle, dedaunan, atau bahan yang disediakan oleh alam. Permainan ini, merujuk pada aktivitas dan 
kreatifitas seorang anak dalam membuat atau membangun sesuatu dari bahan yang disediakan.

\section{Pemahaman Firman Tuhan}

Manusia tidak dapat langsung memahami sesuatu secara langsung. Pemahaman tentang data yang masuk ke dalam pikiran manusia mengalami proses data yang diolah. Pikiran itu sangat dipengaruhi oleh waktu dan tempat, masyarakat dan budaya di mana kita hidup (Knitter, 2008, p. 137). Pemahaman firman Tuhan terbentuk dengan penangkapan indera manusia untuk merespons sensasi yang akhirnya membentuk persepsi. Pemahaman firman Tuhan adalah interaksi manusia dengan firman Tuhan dimana firman Allah memberikan pengertian tentang kebenaran Allah (Ronda, 2011, 2013). Allah berfirman melalui firman Allah kepada manusia untuk memberitahukan maksud dan kehendak-Nya. Allah sendiri melalui firman-Nya memberikan pemahaman untuk tujuan melakukan perintah-Nya dan memuliakan nama-Nya. Yesus memberikan perumpamaan, cerita, dan media untuk menjelaskan maksud-Nya untuk umat-Nya. Contohnya khotbah di bukit, uang koin, roti dan ikan, ragi.

\section{Indikator Pemahaman}

Dalam sebuah tingkatan pembelajaran, pemahaman memiliki kedudukan yang lebih tinggi satu tingkat dari pengetahuan. Untuk memahami sesuatu, diperlukan kemampuan untuk menangkap makna atau arti dari suatu konsep. Dalam menangkap arti dari suatu materi, dibutuhkan konsentrasi yang penuh terhadap materi tersebut. Hal tersebut, dapat dilakukan dengan memahami makna dari tiap-tiap kalimat dan mencerna maksud dan tujuan dari kalimat tersebut.

Pemahaman erat kaitannya dengan inti dari sesuatu. Yang merupakan bentuk pengertian atau pemahaman yang menjadi penyebab seseorang mengetahui apa yang sedang dikomunikasikan itu, tanpa harus menghubungkannya dengan bahan lain. Menurut taksonomi Bloom, pemahaman dibedakan menjadi tiga, yaitu penerjemahan (translasi), penafsiran (interpretasi), dan ekstrapolasi (Gunawan \& Palupi, 2016, p. 101).

\section{Penerjemahan}

Penerjemahan atau biasa disebut translasi merupakan kemampuan untuk memahami suatu ide yang dinyatakan dengan cara lain dari pada pernyataan asli yang dikenal sebelumnya (Gunawan \& Palupi, 2016, p. 101). Artinya, bahwa proses untuk memberi makna atau memberi pengertian dari pengetahuan yang diterima, dapat dilakukan dengan memberikan makna sesuai yang dimengerti. Ketika seseorang memperoleh informasi atau pengetahuan yang baru, akan ada perbedaan bagaimana orang tersebut memaknai hal yang diterimanya dengan orang lain. 
Pemahaman dibuktikan melalui ketelitian dan ketepatan untuk menginterpretasikan atau menerjemahkan satu bahasa ke bahasa lain atau satu bentuk ke bentuk yang lain (Iskandar \& Syahir, 2018, p. 32). Artinya, memahami sesuatu dibuktikan melalui ketelitian untuk menguraikan atau mengartikan sesuatu ke bahasa lain, atau ke bentuk yang lain. Penerjemahan dapat diartikan sebagai pengertian lain.

\section{Penafsiran}

Penafsiran atau biasa disebut interpretasi merupakan penjelasan atau rangkuman atas suatu komunikasi, misalnya menafsirkan berbagai data sosial yang direkam, diubah, atau disusun dalam bentuk lain seperti grafik, tabel, diagram (Gunawan \& Palupi, 2016, p. 101). Dengan kata lain, penafsiran berarti memberikan penjelasan secara singkat atas suatu komunikasi dengan menggunakan bahasa pribadi. Dari penjelasan singkat tersebut yang kemudian dijadikan rangkuman atas komunikasi atau informasi yang didapatkan.

Penafsiran merupakan "aktivitas intelektual yang prosesnya mencerminkan penggunaan asumsi, konsep, dan paradigma" (Risdiana, 2016, p. 23). Artinya bahwa, dalam proses penafsiran, ada perubahan yang terjadi. Baik itu kerangka berfikir, rancangan yang ada, dan hal-hal lain yang digunakan untuk memahami sesuatu.

\section{Ekstrapolasi}

Ekstrapolasi yaitu meluaskan kecenderungan melampaui datanya untuk menentukan atau mengetahui implikasi, konsekuensi, akibat, pengaruh sesuai kondisi suatu fenomena pada awalnya (Iskandar \& Syahir, 2018, p. 33). Seperti membuat kesimpulan dari pernyataan-pernyataan yang ada, dan memprediksi hal lain yang mungkin akan terjadi. Kesimpulan memberikan makna yang tersendiri bagi seseorang. Pemberian kesimpulan juga dapat dimaknai secara berbeda pada setiap orang.

Dalam sebuah kesimpulan, ada implikasi dan aplikasi yang perlu diterapkan. Penerapan tersebut bertujuan sebagai pembuktian kemampuan pengertian dari apa yang telah dipelajari. Dengan demikian, memampukan seseorang untuk dapat melakukan perubahan dari yang tidak paham, menjadi dapat memberikan kesimpulan.

\section{METODE}

Metode peneltian kuantitatif dengan menggunakan rumus Rating Skala (Sugiyono, 2014; Wijaya, 2016, pp. 80-81) untuk melihat hubungan metode permainan terhadap pemahaman firman Tuhan. Perlakuan jenis metode permainan diberikan kepada remaja jemaat GKII Okahapi. Pengumpulan data dilakukan dengan penyebaran angket, observasi, dan wawancara (Helaluddin \& Wijaya, 2019). Hasil 
Rating Skala diintrepretasikan berdasarkan hasil penelitian, dan dikorelasikan dengan teori yang ada menghasilkan simpulan penelitian.

\section{HASIL DAN PEMBAHASAN}

\section{Subjek Penelitian}

Dalam penelitian ini, peneliti melakukan penelitian melalui angket yang dibagikan kepada 20 (dua puluh) orang anak remaja GKII Okahapi Sumba Timur sebagai objek penelitian. Dua puluh responden mengikuti metode permainan, dan aktif terlibat dan memberikan respons dengan menjawab 50 butir pernyataan yang berkaitan dengan variabel jenis metode permainan $(X)$ dan variable pemahaman firman Tuhan (Y).

\section{Deskriptif Analisis Data Penelitian}

\section{Metode Permainan Bermain Fungsional $\left(\mathrm{X}_{1}\right)$ terhadap Pemahaman Firman Tuhan}

Berdasarkan hasil penelitian, diperoleh hasil perhitungan rating skala untuk indikator variabel $X_{1}$ (bermain fungsional) memengaruhi indikator $Y_{1}$ (penerjemahan) yakni sebesar 93,75\%. Hal ini menunjukkan bahwa variabel $X_{1}$ mampu memengaruhi $\mathrm{Y}_{1}$ dengan baik, sehingga pemahaman firman Tuhan pada permainan memberi harga dapat diterjemahkan secara pribadi oleh masing-masing remaja. Persentase yang menjawab sangat setuju lebih banyak dibandingkan dengan responden yang menjawab setuju. Responden yang menjawab sangat setuju dapat memaknai firman Tuhan yang disampaikan melalui permainan tersebut. Remaja dapat memberi pengertian secara pribadi mengenai pemahaman yang didapatkan.

Hasil perhitungan rating skala untuk indikator variabel $\mathrm{X}_{1}$ (bermain fungsional) memengaruhi indikator $Y_{2}$ (penafsiran) yakni sebesar 94,58\%. Hal ini menunjukkan bahwa variabel $X_{1}$ mampu memengaruhi $Y_{2}$ dengan baik, sehingga pemahaman firman Tuhan pada permainan Simson, Delila, dan Singa dapat ditafsirkan maksudnya secara pribadi oleh masing-masing remaja. Persentase menjawab sangat setuju lebih banyak dibandingkan dengan yang setuju. Tidak ada responden yang memberi jawaban tidak setuju terhadap hubungan menafsirkan dengan permainan fungsional Simson Delila, dan Singa. Dengan demikian diketahui bahwa remaja mampu menafsirkan fungsi tokoh-tokoh Alkitab yang diperankan.

Hasil perhitungan rating skala untuk indikator variabel $\mathrm{X}_{1}$ (bermain fungsional) memengaruhi indikator $Y_{3}$ (ekstrapolasi) yakni sebesar 93,75\%. Hal ini menunjukkan bahwa variabel $X_{1}$ mampu memengaruhi $Y_{3}$ dengan baik, sehingga pemahaman firman Tuhan dapat diterjemahkan secara pribadi oleh masing-masing remaja. Persentase menjawab sangat setuju lebih banyak dibandingkan dengan yang menjawab setuju. Ada 1 responden yang memberi jawaban tidak setuju untuk mau bekerja sama dengan orang lain, dan tidak ada responden yang memberi jawaban 
tidak setuju terhadap hubungan menerjemahkan dengan permainan holding hands. Narasumber yang memberi respons tidak setuju untuk berpegang tangan sampai permainan selesai mengatakan, "la tidak mau turut dalam menyelesaikan tantangan yang sedang dihadapi, dan tidak percaya lagi bahwa ia mampu menyelesaikan permainannya bersama dengan kelompok" (Tiara Djami, Wawancara Oleh Penulis, Sumba Timur, 16 Juni 2019).

\section{Metode Permainan Bermain Peran $\left(\mathrm{X}_{2}\right)$ terhadap Pemahaman Firman Tuhan}

Berdasarkan hasil penelitian, diperoleh hasil perhitungan rating skala untuk indikator variabel $X_{2}$ memengaruhi indikator $Y_{1}$ yakni sebesar 94,16\%. Hal ini menunjukkan bahwa variabel $X_{2}$ mampu memengaruhi $Y_{1}$ dengan baik, sehingga pemahaman firman Tuhan dapat diterjemahkan secara pribadi oleh masing-masing remaja. Hasil persentase menjawab sangat setuju lebih banyak dibandingkan dengan yang setuju, dan $0 \%$ yang memberi jawaban tidak setuju dan sangat tidak setuju.

Berdasarkan hasil penelitian, diperoleh hasil perhitungan rating skala untuk indikator variabel $X_{2}$ memengaruhi indikator $Y_{2}$ yakni sebesar 95\%. Hal ini menunjukkan bahwa variabel $X_{2}$ mampu memengaruhi $Y_{2}$ dengan baik, sehingga pemahaman firman Tuhan dapat diterjemahkan secara pribadi oleh masing-masing remaja. Hasil persentase menjawab sangat setuju lebih banyak dibandingkan dengan yang setuju, dan 0 persen yang memberi jawaban tidak setuju dan sangat tidak setuju. Salah satu responden mengatakan, bahwa "Singa dapat dikalahkan oleh Simson, tetapi Simson bisa dikalahkan oleh rayuan Delila, tetapi Delila sangat takut kepada singa. Simson gagal mengenali kelemahannya dan mengatasinya walaupun dia cukup mengenali kekuatannya. Tuhan ingin kita tidak hanya sebatas mengenali kekuatan kita, melainkan juga mengenali kelemahan kita. dan memperbaikinya bersama dengan Tuhan" (Siprianus Lima Migu, Wawancara Oleh Penulis, Sumba Timur, 16 Juni 2019). Terlihat dari jawaban anak remaja bahwa, anak remaja dengan pemahaman yang dimiliki dapat merangkumkan makna yang diperoleh dari permainan simson delila singa.

Berdasarkan hasil penelitian, diperoleh hasil perhitungan rating skala untuk indikator variabel $X_{2}$ memengaruhi indikator $Y_{3}$ yakni sebesar 94,16\%. Hal ini menunjukkan bahwa variabel $X_{2}$ mampu memengaruhi $Y_{3}$ dengan baik, sehingga pemahaman firman Tuhan dapat diterjemahkan secara pribadi oleh masing-masing remaja. Hasil persentase menjawab sangat setuju lebih banyak dibandingkan dengan yang setuju, dan $0 \%$ yang memberi jawaban tidak setuju dan sangat tidak setuju.

\section{Metode Permainan Bermain Konstruktif $\left(X_{3}\right)$ terhadap Pemahaman Firman Tuhan}

Berdasarkan hasil penelitian, diperoleh hasil untuk indikator variabel $X_{3}$ memengaruhi indikator $Y_{1}$ yakni sebesar $93,75 \%$. Hal ini menunjukkan bahwa variabel $\mathrm{X}_{3}$ mampu memengaruhi $\mathrm{Y}_{1}$ dengan baik, sehingga pemahaman firman Tuhan dapat diterjemahkan secara pribadi oleh masing-masing remaja. Persentase menjawab 
sangat setuju lebih banyak dibandingkan dengan yang setuju. Salah satu narasumber yang memberi respons sangat setuju mengatakan bahwa "Sebagai remaja Kristen, tentunya kita harus menjadi panutan bagi orang-orang yang ada di sekitar kita. Tidak usah terpengaruh oleh perkataan orang lain yang mungkin tidak membangun karakter yang baik dalam hidup kita. Mari menghargai anugerah yang diberikan Tuhan" (Siska Asriani Tola, Wawancara Oleh Penulis, Sumba Timur, 16 Juni 2019). Dari pendapat remaja tersebut mengambarkan bahwa sebagai seorang remaja harus menjadi panutan bagi remaja yang lain, jangan mau terpengaruh dengan perkataan orang lain. Karena Tuhan sudah menciptakan manusia dengan keunikan yang berbeda-beda.

Berdasarkan hasil penelitian, diperoleh hasil perhitungan rating skala untuk indikator variabel $X_{3}$ memengaruhi indikator $Y_{2}$ yakni sebesar 91, 66\%. Hal ini menunjukkan bahwa variabel $X_{3}$ mampu memengaruhi $Y_{2}$ dengan baik, sehingga pemahaman firman Tuhan dapat diterjemahkan secara pribadi oleh masing-masing remaja. Hasil persentase menjawab sangat setuju lebih banyak dibandingkan dengan yang setuju, dan 2 orang yang memberi jawaban tidak setuju dan 0 responden yang memberi jawaban sangat tidak setuju. Adapun menurut responden alasan mengapa tidak setuju dengan untuk dapat mendengarkan pendapat orang lain yaitu "tidak semua orang dapat mendengarkan orang lain. Mereka sulit untuk bekerja sama dengan remaja lainnya jika mereka tidak mau mendengar pendapat dari setiap pribadi" (Gita Sari Yemima Indah Kihi dan Tiara Djami, Wawancara Oleh Penulis, Sumba Timur, 16 Juni 2019).

Berdasarkan hasil penelitian, diperoleh hasil perhitungan rating skala untuk indikator variabel $X_{3}$ memengaruhi indikator $Y_{3}$ yakni sebesar 94,16\%. Hal ini menunjukkan bahwa variabel $X_{3}$ mampu memengaruhi $Y_{3}$ dengan baik, sehingga pemahaman firman Tuhan dapat diterjemahkan secara pribadi oleh masing-masing remaja. Hasil persentase menjawab sangat setuju lebih banyak dibandingkan dengan yang setuju, dan 0 persen yang memberi jawaban tidak setuju dan sangat tidak setuju. Salah satu responden sangat setuju memberikan respons, bahwa "berpegangan tangan sampai permainan selesai, berarti memiliki keinginan bersama dengan remaja lain untuk bersatu hati dalam menyelesaikan masalah yang dihadapi. Berpegang tangan dengan orang lain, itu sama halnya dengan memegang tangan Tuhan dalam hidup" (Nona Bunga, Wawancara Oleh Penulis, Sumba Timur, 16 Juni 2019). Remaja menyadari bahwa ada keinginan bersama untuk mau menghadapi dan menyelesaikan tantangan bersama.

\section{KESIMPULAN}

Hasil penelitian menunjukkan bahwa $X_{2}$ memengaruhi indikator $Y_{2}$ yang paling besar di antara indikator yang lain, yaitu sebesar $95 \%$. Hal ini menunjukkan bahwa metode bermain peran memiliki pengaruh yang besar dalam meningkatkan pemahaman penafsiran firman Tuhan. Penggunaan metode permainan dalam 
kegiatan ibadah dapat meningkatkan pemahaman firman Tuhan pada remaja GKII

Okahapi Sumba Timur. Penerapan bermain peran membantu anak remaja untuk dapat mengerti cara untuk membangun persekutuan yang benar di dalam Tuhan. Remaja dengan pemahaman yang dimiliki dapat merangkumkan makna yang diperoleh dari bermain peran. Hal tersebut menjadikan remaja mau mendengarkan perkataan orang lain, mau bekerja sama, dan mau belajar rendah hati. Metode permainan membatu remaja untuk menerjemahkan maksud dengan perkataannya sendiri, menafsirkan makna firman Tuhan, dan mengkontruksi kembali makna firman Tuhan untuk disampaikan kembali kepada orang lain.

\section{KEPUSTAKAAN}

Anwar, M. (2018). Menjadi Guru Profesional. Prenada Media.

Agung, I., \& Astika, M. (2011). Penerapan Metode Mengajar Yesus Menurut Injil Sinoptik Dalam Pelaksanaan Pendidikan Agama Kristen Di SMA Gamaliel Makassar. Jurnal Jaffray, 9(2), 147-171. https://doi.org/10.25278/jj71.v9i2.99.

Baharsyah, M. I. (2017). Peningkatan pemahaman karakter tokoh pewayangan punakawan bahasa jawa dengan menggunaka media wayang dua dimensi pada siswa kelas V MI Miftahul Ulum Kraton Krian Sidoarjo [Undergraduate, UIN Sunan Ampel Surabaya]. http://digilib.uinsby.ac.id/19292/.

Bayoe, Y. V., Kouwagam, M. L., \& Tanyit, P. (2019). Metode Pembelajaran Melalui Film Superbook dan Minat Belajar Firman Tuhan Pada Anak Usia 6-8 Tahun. Jurnal Jaffray, 17(1), 141-156. https://doi.org/10.25278/jj71.v17i1.327.

D. Gunarsa, S., \& Singgih D. Gunarsa, Y. (2011). Psikologi Perkembangan Anak Dan Remaja. BPK Gunung Mulia.

Darmadi. (2018). Asyiknya Belajar Sambil Bermain. Guepedia.

Edison, T. (2017). 52 Metode Mengajar: Mengangkat Harkat dan Martabat Pendidik Menjadi Berwibawa dan Terhormat. Kalam Hidup.

Gibasa, T., Zaman, S., \& R. Helmi, D. (2010). Games Kreatif Pilihan untuk Meningkatan Potensi Diri dan Kelompok. GagasMedia.

Gunawan, I., \& Palupi, A. R. (2016). Taksonomi Bloom - Revisi Ranah Kognitif: Kerangka Landasan Untuk Pembelajaran, Pengajaran, Dan Penilaian. Premiere Educandum: Jurnal Pendidikan Dasar dan Pembelajaran, 2(02). https://doi.org/10.25273/pe.v2i02.50.

Hapsari, D., \& Wicaksono, V. D. (2012). Pengaruh Metode Permainan Bingo Terhadap Motivasi Dan Pemahaman Materi PPKN Kelas IV SDN Sumokembangsri Sidoarjo. JPGSD, 01(01), 1-11.

http://jurnalmahasiswa.unesa.ac.id/index.php/jurnal-penelitianpgsd/article/download/23980/21920.

Helaluddin, H., \& Wijaya, H. (2019). Analisis Data Kualitatif: Sebuah Tinjauan Teori \& Praktik. Sekolah Tinggi Theologia Jaffray Makassar.

Iskandar, S., \& Syahir, M. (2018). Filsafat Pendidikan Vokasi. Deepublish. 
Masnipal. (2013). Siap Menjadi Guru \& Pengelola PAUD Profesional. Elex Media Komputindo.

Migu, S. L. (2019, June 16). Alasan Sangat Setuju [Personal communication].

Mutiah, D. (2015). Psikologi Bermain Anak Usia Dini. Prenada Media Group.

Nikmah, S., Kartono, \& Halidjah, S. (2013). Penggunaan Metode Permainan Dalam Pembelajaran IPA Untuk Meningkatkan Aktivitas Dan Hasil Belajar Siswa Kelas IV Sekolah Dasar Negeri 11 Sungai Melayu Rayak. Jurnal Pendidikan Dan Pembelajaran Khatulistiwa, 2(3).

http://jurnal.untan.ac.id/index.php/jpdpb/article/view/1207.

Nurhasanah, S., \& Sobandi, A. (2016). Minat Belajar Sebagai Determinan Hasil Belajar Siswa. Jurnal Pendidikan Manajemen Perkantoran, 1(1), 135-142.

Risdiana, Y. (2016). Penafsiran Kontrak Komersial Antara Teks Dan Konteks. Inboeku Media Ilmu.

Ronda, D. (2011). Leadership Wisdom. Kalam Hidup. . (2013). Dasar Teologi yang Teguh: Panduan Teologi Sistematika Di Perguruan Tinggi. Sekolah Tinggi Theologia Jaffray Makassar.

Sugiyono. (2014). Metode Penelitian Pendidikan Pendekatan Kuantitatif, Kualitatif, dan $R \& D$. Alfabeta.

Supardi, Leonard, L., Suhendri, H., \& Rismurdiyati, R. (2015). Pengaruh Media Pembelajaran dan Minat Belajar Terhadap Hasil Belajar Fisika. Formatif: Jurnal Ilmiah Pendidikan MIPA, 2(1). https://doi.org/10.30998/formatif.v2i1.86.

Syarbini, A. (2014). Model Pendidikan Karakter Dalam Keluarga. Elex Media Komputindo.

Tim Budi Pekerti. (n.d.). Terbang Dgn Dua Sayap. Grasindo.

Wijaya, H. (2016). Metodologi Penelitian Pendidikan Teologi. Sekolah Tinggi Theologia Jaffray Makassar. 